$33.9 \%$ squamous cell carcinoma, $7.3 \%$ large cell carcinoma, $6.1 \%$ other. The data is summarised in the table below:

Conclusion

- Audit over the past 3 years shown steady improvement in lymph node assessment performance.

- Continuous auditing and presentation of individual surgeon data at local, regional and national forums has contributed to the increasing compliance to the guideline targets

- There remains scope for further improvement and consultant engagement.

- Re-auditing will be essential to further improve compliance with guidelines.

\section{P225 REVISED BTS GUIDELINES FOR SECURING CANCER DIAGNOSIS AT BRONCHOSCOPY - A HIGHER RECOMMENDED YIELD IS REALISTIC AND ACHIEVABLE}

AE Stanton, CI Mackinlay. Department of Respiratory Medicine, Great Western Hospitals NHS Foundation Trust, Swindon, UK

10.1136/thoraxjnl-2014-206260.354

Introduction The recently updated BTS guidelines ${ }^{1}$ on bronchoscopy recommend that a diagnostic level of $85 \%$ should be attainable when definite endobronchial tumour is visible, an increase from previous recommendation of $80 \%$. We investigated whether this higher level was achievable.

Methods All patients undergoing bronchoscopy for suspected lung cancer were prospectively entered into a departmental database from April 2010, with performance analysed annually. The following specific data were entered: level of tumour presence (none seen / possible / definite tumour); diagnostic specimens taken (biopsy, brush, wash, TBNA); result of each diagnostic specimen (tumour present / not present, with reports "suspicious or suggestive" of tumour classified as "not present" unless there was a specific MDT decision to give a cancer diagnosis), and whether bronchoscopy was diagnostic of lung cancer overall. Finally clinical records were reviewed in patients without a bronchoscopic diagnosis of cancer to determine their final diagnosis. Results In the 4 full years since commencement of data collection, 356 bronchoscopies were performed for suspected lung cancer, with confirmed cancer diagnosis in 301. Table 1 summarises diagnostic sensitivity for endobronchial biopsy, brush, wash and overall sensitivity for lung cancer diagnosis at bronchoscopy in patients with bronchoscopically definite tumour seen. In $3 / 4$ years our overall diagnostic sensitivity has reached the level recommended (86.4-91.7\%), with first year performance just below the new standard (84.4\%).

Conclusions The revised level of recommended diagnostic rate at bronchoscopy for definite tumour appears to be realistic and achievable. This should remain as the standard of care for patients undergoing bronchoscopy for suspected lung cancer.
REFERENCE

BTS Guideline for diagnostic flexible bronchoscopy in adults. Thorax 2013;68(Suppl 1)

P226 WITHDRAWN

\section{Asthma treatments}

\section{P227 EFFICACY AND SAFETY OF BUDESONIDE-FORMOTEROL (BF) SPIROMAX® IN ADULTS AND ADOLESCENTS WITH ASTHMA: RANDOMISED COMPARISON WITH BF TURBUHALER $®$}

${ }^{1} \mathrm{JC}$ Virchow, ${ }^{2} \mathrm{G}$ Gopalan, ${ }^{3} \mathrm{R}$ Rodriguez-Roisin, ${ }^{2} Y$ Shu. ${ }^{1}$ University Hospital Rostock, Rostock, Germany; ${ }^{2}$ Teva Pharmaceuticals, West Chester, USA; ${ }^{3}$ Universitat de Barcelona Villarroel, Barcelona, Spain

\subsection{6/thoraxjnl-2014-206260.355}

Background DuoResp Spiromax ${ }^{\circledR}$ (Teva Pharmaceuticals) is a dry-powder inhaler designed to deliver budesonide and formoterol fumarate (BF Spiromax ${ }^{\circledR}$ ) with maximum ease of use. Pharmacokinetic studies have shown bioequivalence of $\mathrm{BF}$ Turbuhaler $^{\circledR}$. This study compared the efficacy and safety of these devices in patients with asthma.

Methods This was a 12-week, multicentre, double-blind, randomised, controlled trial $(\mathrm{N}=605)$. Eligible patients $(\geq 12$ years old) had persistent asthma with $\mathrm{FEV}_{1} 40-85 \%$ predicted, had used a SABA and ICS for $\geq 8$ weeks before screening and were maintained on stable-dose ICS for 4 weeks. The primary objective was to demonstrate non-inferiority of twice-daily BF Spiromax ${ }^{\circledR} 160 /$ $4.5 \mathrm{mcg}$ to BF Turbuhaler ${ }^{\circledR} 200 / 6 \mathrm{mcg}$, with respect to change from baseline in weekly average of daily trough morning PEF.

Results This analysis was based on the per protocol population $\left(\mathrm{N}=290\right.$ and $\mathrm{N}=284$ for BF Spiromax ${ }^{\circledR}$ and BF Turbuhaler ${ }^{\circledR}$ groups, respectively). The least squares mean change from baseline to Week 12 in morning PEF was $18.8 \mathrm{~L} / \mathrm{min}$ with BF Spi$\operatorname{romax}^{\circledR}$ and $21.796 \mathrm{~L} / \mathrm{min}$ with BF Turbuhaler ${ }^{\circledR}$. Noninferiority of BF Spiromax ${ }^{\circledR}$ vs BF Turbuhaler $^{\circledR}$ was demonstrated, as the lower limit of the $95 \%$ two-sided CI $(-9.02 \mathrm{~L} /$ $\min$ ) is greater than $-15 \mathrm{~L} / \mathrm{min}$. Similarly, no significant between-group differences were observed in secondary efficacy endpoints. Both devices were well tolerated, with no significant differences in the incidence of adverse events or asthma exacerbations.

Conclusions This study has demonstrated the non-inferiority of BF Spiromax ${ }^{\circledR}$ vs BF Turbuhaler $^{\circledR}$ in adults and adolescents with asthma. Further data are required to confirm whether BF Spiromax ${ }^{\circledR}$ can be used as an alternative to BF Turbuhaler ${ }^{\circledR}$ in other indications. Sponsor: Teva Pharmaceuticals.

\begin{tabular}{|c|c|c|c|c|c|c|c|}
\hline Year & $\begin{array}{l}\text { No. of Bronchs - } \\
\text { Suspected LC }\end{array}$ & $\begin{array}{l}\text { No. with } \\
\text { confirmed LC }\end{array}$ & $\begin{array}{l}\text { No. of bronchs - } \\
\text { definite tumour seen }\end{array}$ & $\begin{array}{l}\text { Biopsy } \\
\text { sensitivity (\%) }\end{array}$ & $\begin{array}{l}\text { Brushing sensitivity } \\
(\%)\end{array}$ & $\begin{array}{l}\text { Washing sensitivity } \\
(\%)\end{array}$ & $\begin{array}{l}\text { Overall sensitivity when } \\
\text { definite tumour seen (\%) }\end{array}$ \\
\hline 2010-11 & 92 & 72 & 33 & 67.7 & 66.7 & 43.8 & 84.4 \\
\hline 2011-12 & 87 & 71 & 41 & 80.6 & 60.7 & 27.8 & 86.4 \\
\hline 2012-13 & 90 & 81 & 52 & 81.3 & 55.8 & 30.6 & 86.5 \\
\hline 2013-14 & 87 & 77 & 36 & 80 & 71.4 & 47.2 & 91.7 \\
\hline
\end{tabular}

